\title{
Cyclization-activated prodrugs. Synthesis, reactivity and toxicity of dipeptide esters of paracetamol
}

\author{
Cledir Santos, ${ }^{\mathrm{a}}$ Maria Luísa Mateus, ${ }^{\mathrm{b}}$ Ana Paula dos Santos, ${ }^{\mathrm{b}}$ Rui Moreira, ${ }^{\mathrm{b}}$ \\ Eliandre de Oliveira ${ }^{\mathrm{c}}$ and Paula Gomes ${ }^{\mathrm{a}, *}$ \\ ${ }^{a}$ CIQUP, Departamento de Química, Faculdade de Ciências do Porto, P-4169-007 Porto, Portugal \\ ${ }^{\mathrm{b}}$ CECF, Faculdade de Farmácia de Lisboa, P-1600-083 Lisboa, Portugal \\ ${ }^{\mathrm{c}}$ Proteomics Platform, Barcelona Science Park, E-08028 Barcelona, Spain
}

Received 2 December 2004; revised 21 January 2005; accepted 27 January 2005

\begin{abstract}
Dipeptide esters of paracetamol were prepared in high yields. These compounds are quantitatively hydrolyzed to paracetamol and corresponding 2,5-diketopiperazines at $\mathrm{pH} 7.4$ and $37^{\circ} \mathrm{C}$. The reactivity is increased in sarcosine and proline peptides and decreased by bulky side chains at both the $\mathrm{N}$ - and C-terminal residues of the dipeptide carrier. Moreover, dipeptide esters of paracetamol did not affect the levels of hepatic glutathione. Thus, dipeptides seem promising candidates as carriers for cyclizationactivated prodrugs.
\end{abstract}

(C) 2005 Elsevier Ltd. All rights reserved.

Phenol drugs are attractive targets for prodrug design due to their extensive first-pass metabolism. ${ }^{1}$ In the case of paracetamol, 1 (Scheme 1), the metabolism can lead to serious hepatic and renal toxic effects. ${ }^{2}$ These toxic side-effects have been ascribed to the formation of a $\mathrm{N}$-acetylquinone imine, ${ }^{3}$ which is detoxified by reaction with glutathione leading to glutathione depletion and cell death. ${ }^{3,4}$

Esterification of paracetamol with amino acids was reported as a means to obviate the severe hepatotoxicity of the drug at high doses ${ }^{5}$ as well as to increase aqueous
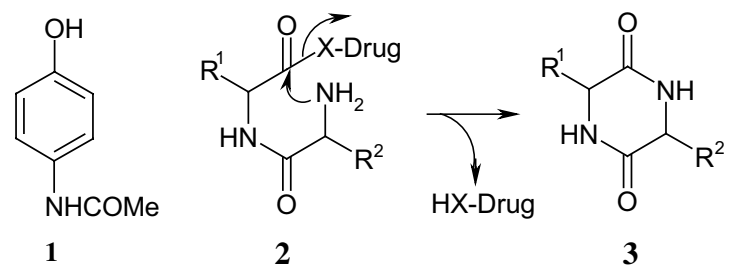

Scheme 1.

$\overline{\text { Keywords: }}$ Cyclization-activated; Paracetamol; Peptide carrier; Prodrug.

*Corresponding author. Tel./fax: +351 22 6082863; e-mail: pgomes@ fc.up.pt solubility. ${ }^{6}$ We now report that dipeptides may also be used as carriers for hydroxyl-containing drugs. Dipeptide esters and amides (2, X $=\mathrm{O}$ or $\mathrm{NH}$, Scheme 1) can deliver the parent drug through enzyme-independent processes such as the intramolecular cyclization to form the corresponding diketopiperazines (3, DKPs, Scheme 1). ${ }^{7,8}$ The major drawback of using dipeptides as carrier candidates for prodrugs is their susceptibility to non-specific peptidases. However, enzymatically stable dipeptides (e.g., containing 2-aminoisobutyric acid or $\mathrm{N}$-methylglycine as carriers) have been used successfully to improve physico-chemical properties of cytarabine $^{9}$ and cyclosporine. ${ }^{10}$ Despite the potential of dipeptides as carriers for cyclization-activated prodrugs, there is a lack of systematic information concerning the effect of the peptide structure on the rate of drug release under physiological conditions. Herein we report the synthesis and the chemical reactivity of dipeptide esters of paracetamol, 4, encompassing a wide range of amino acid residues to evaluate the suitability of dipeptide esters as potential cyclization-activated prodrugs of paracetamol. In addition, the potential hepatotoxicity of several paracetamol derivatives was studied by evaluating the effect on the hepatic levels of glutathione in mice.

Paracetamol esterification was based on the $O$-(benzotriazol-1-yl)- $N, N, N^{\prime}, N^{\prime}$-tetramethyluronium 


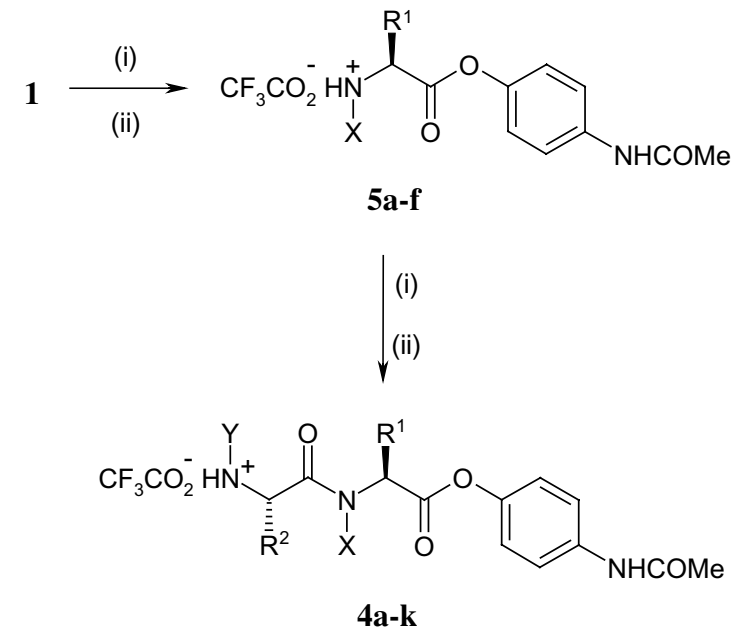

Scheme 2. Reagents: (i) $N^{\alpha}$-BocAAOH, TBTU, DIEA, dichloromethane; and (b) $\mathrm{KHSO}_{4}, \mathrm{Na}_{2} \mathrm{CO}_{3}$ : ca. $90 \%$ yield; (ii) TFA, ethyl ether: ca. $93 \%$ yield.

tetrafluoroborate (TBTU) coupling reagent usually employed in peptide synthesis. $\mathrm{N}^{\alpha}$-Boc-protected amino acids were coupled to paracetamol and the $\mathrm{N}^{\alpha}$-protecting group subsequently removed by acidolysis with trifluoroacetic acid to form the unprotected esters $\mathbf{5}$ (Scheme 2). ${ }^{11}$ This procedure led to higher overall yields (ca. 70\%) than those previously achieved by the mixed anhydride method (ca. 35\%). ${ }^{5}$ The esters, 5, thus obtained were easily reacted with a second $\mathrm{N}^{\alpha}$-Boc-protected amino acid, again via TBTU-coupling. The final products, 11 dipeptide esters of paracetamol, $\mathbf{4 a}-\mathbf{k}$, were also obtained as trifluoroacetates (Scheme 2).

The dipeptide esters 4 were incubated in $\mathrm{pH} 7.4$ phosphate buffer at $37^{\circ} \mathrm{C}$ and reaction progress was monitored by HPLC, using paracetamol and adequate DKPs as standards for product identification. ${ }^{12}$ The pseudo-first-order rate constants for the degradation of derivatives 4 are presented in Table 1. Paracetamol and DKPs were quantitatively released, as measured by HPLC, which is consistent with an intramolecular acyl transfer reaction (Scheme 2, $\mathrm{X}=\mathrm{O}$ ). The formation of DKPs has also been reported as a major degradation pathway for simple alkyl esters ${ }^{13-16,15}$ and 4-nitroaniline amides $^{7}$ of dipeptides. For compounds $\mathbf{4}$, which contain a much better leaving group (the $\mathrm{p} K_{\mathrm{a}}$ for paracetamol is $9.7^{17}$ ) cyclization remains the major degradation pathway. The better leaving group ability of paracetamol, when compared to aliphatic alcohols, leads to increased reactivity. For example, the Gly-Phe ester $\mathbf{4 d}$ is ca. 80 times more reactive than its methyl ester counterpart, at $\mathrm{pH} 7.4$ and $37^{\circ} \mathrm{C} .{ }^{16}$

From the data presented in Table 1, the following observations can be made. First, the rate of paracetamol release at $\mathrm{pH} 7.4$ depends on the size of the side chain of the peptide carrier C-terminal residue: for the Gly-AA series, the order of reactivity is Gly-Gly, $\mathbf{4 a}>$ Gly-Ala, 4b $>$ Gly-Phe, 4d $>$ Gly-Val, 4c. This suggests that increase in steric hindrance close to the ester functionality reduces the rate of cyclization. Second, the rate of paracetamol release also depends on the nature of the N-terminal amino acid of the dipeptide carrier. Indeed, a similar trend is observed for the AA-Gly series, that is, Gly-Gly, 4a > Ala-Gly, 4g > Phe-Gly, 4i > Val-Gly, $\mathbf{4 h}$. Interestingly, a good correlation was observed between $\log k_{\text {obs }}$ for the AA-Gly series and the Charton steric constants $v^{18}$ with a negative slope of -1.72 (Fig. 1, $\left.r^{2}=0.95\right)$, which indicates that the reactivity decreases with increasing size of the amino acid side chain. Third, some of the derivatives of the Gly-AA series release par-

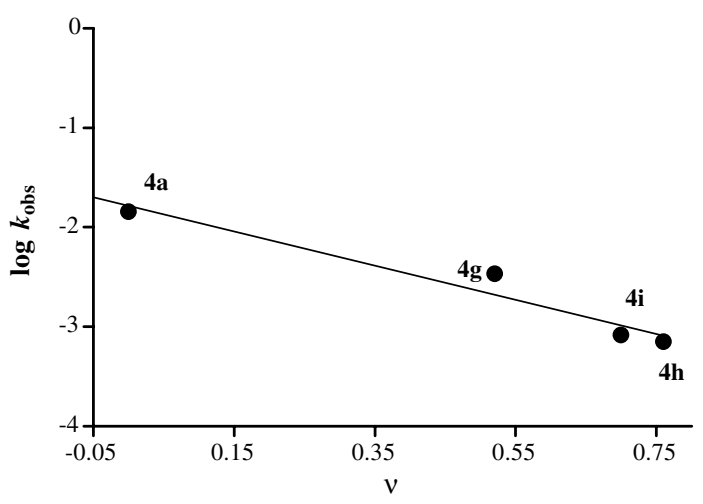

Figure 1. First-order rate constants for the formation of diketopiperazine from dipeptide esters of paracetamol $\mathbf{4 a}, \mathbf{g}-\mathbf{i}$, as a function of Charton steric parameter $v$, at $\mathrm{pH} 7.4$ and $37^{\circ} \mathrm{C}$.

Table 1. Rate constants for the release of paracetamol from dipeptide esters 4 in phosphate buffer at $\mathrm{pH} 7.4$ and $37^{\circ} \mathrm{C}$

\begin{tabular}{|c|c|c|c|c|c|c|c|}
\hline Compound & $\mathrm{R}^{1}$ & $X$ & $\mathrm{R}^{2}$ & $\mathrm{Y}$ & $k_{\mathrm{obs}} / \mathrm{s}^{-1}$ & $t_{1 / 2} / \min$ & $k_{\text {relative }}$ \\
\hline $4 a$ & $\mathrm{H}$ & $\mathrm{H}$ & $\mathrm{H}$ & $\mathrm{H}$ & $1.43 \times 10^{-2}$ & 0.8 & 1 \\
\hline $4 b$ & $\mathrm{Me}$ & $\mathrm{H}$ & $\mathrm{H}$ & $\mathrm{H}$ & $1.34 \times 10^{-2}$ & 0.9 & 0.94 \\
\hline $4 c$ & $\mathrm{CHMe}_{2}$ & $\mathrm{H}$ & $\mathrm{H}$ & $\mathrm{H}$ & $5.70 \times 10^{-4}$ & 20 & 0.04 \\
\hline $4 d$ & $\mathrm{CH}_{2} \mathrm{Ph}$ & $\mathrm{H}$ & $\mathrm{H}$ & $\mathrm{H}$ & $5.64 \times 10^{-3}$ & 2 & 0.4 \\
\hline $4 e$ & & & $\mathrm{H}$ & $\mathrm{H}$ & $\mathrm{ND}^{\mathrm{a}}$ & - & - \\
\hline $4 f$ & $\mathrm{H}$ & $\mathrm{Me}$ & $\mathrm{H}$ & $\mathrm{H}$ & $\mathrm{ND}^{\mathrm{a}}$ & - & - \\
\hline $4 g$ & $\mathrm{H}$ & $\mathrm{H}$ & $\mathrm{Me}$ & $\mathrm{H}$ & $3.40 \times 10^{-3}$ & 3 & 0.24 \\
\hline $4 h$ & $\mathrm{H}$ & $\mathrm{H}$ & $\mathrm{CHMe}_{2}$ & $\mathrm{H}$ & $7.10 \times 10^{-4}$ & 16 & 0.05 \\
\hline $4 i$ & $\mathrm{H}$ & $\mathrm{H}$ & $\mathrm{CH}_{2} \mathrm{Ph}$ & $\mathrm{H}$ & $8.21 \times 10^{-4}$ & 14 & 0.06 \\
\hline $4 j$ & $\mathrm{H}$ & $\mathrm{H}$ & \multicolumn{2}{|c|}{$\left(\mathrm{CH}_{2}\right)_{3}$} & $5.90 \times 10^{-3}$ & 2 & 0.41 \\
\hline $4 k$ & $\mathrm{H}$ & $\mathrm{H}$ & $\mathrm{H}$ & $\mathrm{Me}$ & $\mathrm{ND}^{\mathrm{a}}$ & - & - \\
\hline
\end{tabular}

${ }^{\mathrm{a}}$ Too fast to be monitored at $37^{\circ} \mathrm{C}$. 
acetamol faster than their AA-Gly counterparts. For example, the Gly-Ala derivative $\mathbf{4 b}$ is ca. four times more reactive than the Ala-Gly counterpart $\mathbf{4 g}$, and the Gly-Phe ester $4 \mathbf{d}$ is ca. seven times more reactive than the Phe-Gly ester 4i. For the dipeptide derivatives containing proline, it was only possible to monitor the reaction for the Pro-Gly derivative $\mathbf{4 j}$, while the GlyPro counterpart $4 \mathbf{e}$ decomposed too fast to be monitored at $37^{\circ} \mathrm{C}$. Taken together, these results are consistent with a cyclization mechanism for the release of paracetamol from dipeptide esters 4. Indeed, a bulky N-terminal amino acid (e.g., a bulky $\mathrm{R}^{2}$ group in $\mathbf{2}$, Scheme 1) turns the amino group into a sterically hindered nucleophile and, thus, would be expected to reduce the rate of cyclization. In contrast, if paracetamol release was occurring via a nucleophilic attack of water to the ester carbonyl, that is, the general mechanism for ester hydrolysis, then the nature of the N-terminal amino acid would have a negligible effect on reactivity.

Further support for an intramolecular pathway comes from the observation that the sarcosine dipeptides $4 \mathbf{f}$ and $\mathbf{4 k}$, as well as the proline derivative $\mathbf{4 e}$, decompose too fast to be monitored at $37^{\circ} \mathrm{C}$. This behaviour is consistent with DKP formation underlying paracetamol release, since DKPs are readily formed from dipeptides containing amino acids that can easily drive the peptide bond to adopt the cis configuration (e.g., proline, glycine, N-alkyl amino acids). ${ }^{13,19}$ Thus, dipeptides such as Pro-Gly, Gly-Pro, Sar-Gly and Gly-Sar are quite prone to suffer intramolecular cyclization to DKPs, which fully explains the relative rates observed.

The $\mathrm{pH}$-rate profile for the degradation of compound $\mathbf{4 b}$ determined at $25^{\circ} \mathrm{C}$ is presented in Figure 2. As with other dipeptide esters ${ }^{16}$ and amides ${ }^{7}$ cyclization of 4 to DKP is subject to general-base catalysis (data not shown) and the intercepts of plots of $k_{\text {obs }}$ versus buffer concentration were used to build the pH-rate profile. The sigmoid shape of this $\mathrm{pH}$-rate profile can be ascribed to the ionization of the amino group to form the corresponding conjugate acid. The solid line in Figure 2 was achieved using Eq. 1

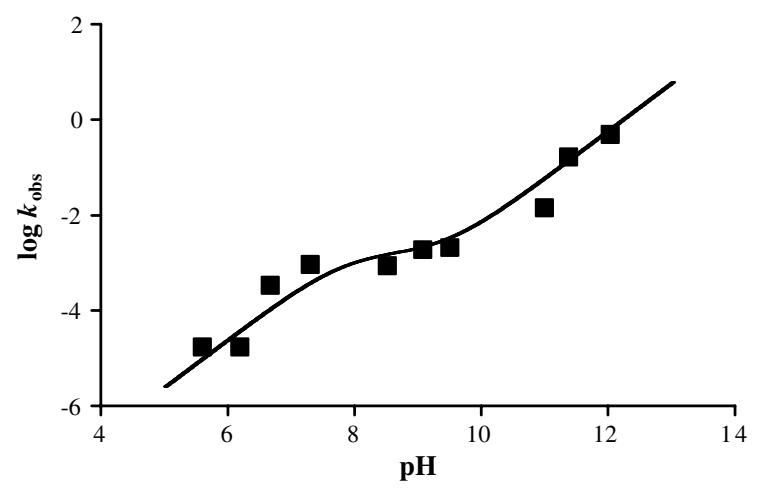

Figure 2. pH-rate profile for the degradation of compound $\mathbf{4 b}$ at $25^{\circ} \mathrm{C}$; ionic strength kept at $0.5 \mathrm{M}$ with $\mathrm{NaClO}_{4}$.

$$
k_{\mathrm{obs}}=\left(k_{\mathrm{OH}}^{-} K_{\mathrm{w}}\left[\mathrm{H}^{+}\right]+k_{\mathrm{OH}}^{-\prime} K_{\mathrm{a}} K_{\mathrm{w}}\right) /\left\{\left(K_{\mathrm{a}}+\left[\mathrm{H}^{+}\right]\right)\left[\mathrm{H}^{+}\right]\right\}
$$

where $K_{\mathrm{a}}$ is the apparent dissociation constant of the protonated amino group in $\mathbf{4 b}$, and $k_{\mathrm{OH}}^{-}$and $k_{\mathrm{OH}}^{-1}$ are the second-order rate constant for the base-catalyzed reaction of the protonated and free base of the substrate, respectively. The best computer fit to the experimental data for $\mathbf{4 b}$ was obtained by using $k_{\mathrm{OH}}^{-}=2500 \mathrm{M}^{-1} \mathrm{~s}^{-1}$, $k_{\mathrm{OH}}^{-1}=62 \mathrm{M}^{-1} \mathrm{~s}^{-1}$ and $K_{\mathrm{a}}=1.58 \times 10^{-8} \mathrm{M}$. The calculated $\mathrm{p} K_{\mathrm{a}}$ value of 7.80 is within the range of $\mathrm{p} K_{\mathrm{a}}$ values reported for other dipeptide esters, that is, 7.6-8.0, which also present $\mathrm{pH}$-rate profiles similar to that of 4b. ${ }^{12,15,16}$ These results indicate that $\mathbf{4 b}$ is more stable for acidic $\mathrm{pH}$ values, that is, when $\mathrm{pH}<\mathrm{p} K_{\mathrm{a}}$ reflecting the predominance of the protonated form of substrate. ${ }^{16,15}$

The effect of prodrugs $\mathbf{4 d}, \mathbf{4 h}$ and $\mathbf{4 i}$, as well as that of the parent paracetamol, on the hepatic levels of glutathione was determined as a measure of hepatotoxicity. ${ }^{20}$ As expected, the group of mice treated ip with $3.3 \mathrm{mmol} / \mathrm{kg}$ paracetamol displayed significantly $(P<0.01)$ lower levels of glutathione when compared with the control group, with a depletion of $61 \%$ (Table 2). In contrast, all the groups of mice treated with derivatives $\mathbf{4 d}, \mathbf{4 h}$ and $4 \mathbf{i}$ showed levels of reduced glutathione comparable to that of the control group ( $P>0.05$; Table 2$)$. These results suggest that hepatotoxicity can be efficiently reduced by attachment of the paracetamol hydroxyl group to a dipeptide. A similar effect was observed with the $(S)$-pyroglutamic acid ester of paracetamol, which led to glutathione hepatic levels in mice superimposable to those of controls. 5

In conclusion, dipeptide carriers can be used to design intramolecular cyclization-activated prodrugs of phenol-containing drugs such as paracetamol. The results herein described positively show that dipeptide esters are quantitatively hydrolyzed to paracetamol and corresponding diketopiperazines at $\mathrm{pH} 7.4$ and $37^{\circ} \mathrm{C}$. The reactivity is decreased by bulky side chains at both the $\mathrm{N}$ - and C-terminal residues of the dipeptide carrier. Although most of dipeptide derivatives of paracetamol 4 are too reactive to be considered as prodrugs, three of them display half-lives ranging from 14 to $20 \mathrm{~min}$ at $\mathrm{pH} 7.4$ and $37^{\circ} \mathrm{C}$. Thomsen and Bundgaard have suggested that practically useful half-lives of conversion for cyclization-activated prodrugs of phenols should range from 10 to $60 \mathrm{~min}$ under those conditions. ${ }^{21} \mathrm{Com}-$ pounds $\mathbf{4}$ also display higher stability at $\mathrm{pH}$ values lower

Table 2. Effect of dipeptide esters 4 and paracetamol on glutathione levels in mice

\begin{tabular}{ll}
\hline & Glutathione $(\mu \mathrm{mol} / \mathrm{g}$ tissue $)$ \\
\hline Control & $3.87 \pm 0.79$ \\
Paracetamol & $1.52 \pm 0.20^{\mathrm{a}}$ \\
$\mathbf{4 d}$ & $3.74 \pm 1.37^{\mathrm{b}}$ \\
$\mathbf{4 h}$ & $3.87 \pm 1.24^{\mathrm{b}}$ \\
$\mathbf{4 i}$ & $2.68 \pm 0.77^{\mathrm{b}}$ \\
\hline
\end{tabular}

${ }^{\text {a }} P<0.01$ compared with control.

${ }^{\mathrm{b}} P>0.05$ compared with control. 
than 7.4. Quite importantly, the in vivo results suggest that hepatotoxicity of paracetamol can be efficiently reduced by an appropriate choice of the dipeptide carrier. The selection of the dipeptide carrier must take in account the potential side-effects of the corresponding DKP formed during the cyclization.

\section{Acknowledgements}

CRS thanks Fundação para a Ciência e Tecnologia (FCT, Portugal) for Ph.D. grant SFRH/BD/9272/2002. PG and RM thank FCT and FEDER for financial support to CIQUP and CECF, respectively.

\section{References and notes}

1. Friis, G. J.; Bundgaard, H. In A Textbook of Drug Design and Development; Krogsgaard-Larsen, P., Liljefors, T., Madsen, U., Eds., 2nd ed.; Harwood Academic: Amsterdam, 1996; p 351.

2. Boyer, T. D.; Rouff, S. L. J. Am. Med. Assoc. 1971, 218, 440.

3. Dahlin, D. C.; Nelson, S. D. J. Med. Chem. 1982, $25,885$.

4. Vermeulen, N. P.; Bessems, J. G.; Van de Straat, R. Drug Metab. Rev. 1992, 24, 367.

5. Bousquet, E.; Marrazzo, A.; Puglisi, G.; Spadaro, A.; Tirendi, S. J. Pharm. Pharmacol. 1996, 48, 479.

6. Kovach, I. M.; Pitman, I. H.; Higuchi, T. J. Pharm. Sci. 1981, 70, 881

7. Goolcharran, C.; Borchardt, R. T. J. Pharm. Sci. 1998, 87, 283.

8. Shan, D.; Nicolaou, M. G.; Borchardt, R. T.; Wang, B. J. Pharm. Sci. 1997, 86, 765.

9. Wipf, P.; Li, W. L.; Adeyeye, C. M.; Rusnak, J. M.; Lazo, J. S. Bioorg. Med. Chem. 1996, 4, 1585.

10. Hamel, A. R.; Hubler, F.; Carrupt, A.; Wenger, R. M.; Mutter, M. J. Pept. Res. 2004, 63, 147.

11. Spectroscopic data for compounds $5 c$ and $4 c(5 c$ is a synthetic precursor of $\mathbf{4 c})$ :

Compound 5c: ${ }^{1} \mathrm{H}$ NMR $\left(\left(\mathrm{CD}_{3}\right)_{2} \mathrm{SO}, 300 \mathrm{MHz}\right): \delta 1.07$ $(3 \mathrm{H}, \mathrm{d}, J=6.9 \mathrm{~Hz}), 1.10(3 \mathrm{H}, \mathrm{d}, J=6.9 \mathrm{~Hz}), 2.04(3 \mathrm{H}, \mathrm{s})$, $4.18(1 \mathrm{H}, \mathrm{d}, J=5.1 \mathrm{~Hz}), 7.11(2 \mathrm{H}, \mathrm{d}, J=8.7 \mathrm{~Hz}), 7.64$ $(2 \mathrm{H}, \mathrm{d}, J=8.7 \mathrm{~Hz}), 8.64(3 \mathrm{H}$, br s $), 10.12(1 \mathrm{H}, \mathrm{s}) ;{ }^{13} \mathrm{C}$ NMR ((CD $\left.)_{2} \mathrm{SO}, 75 \mathrm{MHz}\right): \delta 17.65,18.26,23.86,29.54$, $57.35,120.06,121.50,137.60,144.64,167.93,168.42 ; \mathrm{MW}$ (Da): 250.1935 (calcd, 250.2937).

Compound 4c: ${ }^{1} \mathrm{H}$ NMR $\left(\left(\mathrm{CD}_{3}\right)_{2} \mathrm{SO}, 300 \mathrm{MHz}\right): \delta 1.03$ $(6 \mathrm{H}, \mathrm{d}, J=6.6 \mathrm{~Hz}), 2.04(3 \mathrm{H}, \mathrm{s}), 2.25(1 \mathrm{H}, \mathrm{m}), 3.71(2 \mathrm{H}$, s), $4.45(1 \mathrm{H}, \mathrm{m}), 7.02(2 \mathrm{H}, \mathrm{d}, J=9.0 \mathrm{~Hz}), 7.62(2 \mathrm{H}, \mathrm{d}$, $J=8.7 \mathrm{~Hz}), 8.17(3 \mathrm{H}, \mathrm{s}), 8.88(1 \mathrm{H}, \mathrm{d}, J=7.5 \mathrm{~Hz}), 10.10$ $(1 \mathrm{H}, \mathrm{s}) ;{ }^{13} \mathrm{C}$ NMR $\left(\left(\mathrm{CD}_{3}\right)_{2} \mathrm{SO}, 75 \mathrm{MHz}\right): \delta 18.01,18.86$, 23.82, 29.93, 57.69, 64.85, 119.89, 121.56, 137.21, 145.17, 166.62, 168.26, 170.04; MW (Da): 307.2231 (calcd, $307.3451)$.

12. General procedure for the monitoring of drug release by HPLC: A solution of the compound to be assayed $\left(10^{-4} \mathrm{M}\right)$ in aqueous buffer $(\mathrm{pH} 7.4)$ was kept at a constant temperature of $37.0 \pm 0.1{ }^{\circ} \mathrm{C}$; aliquots were periodically taken and immediately injected (loop of $100 \mu \mathrm{L}$ ) in the HPLC system, using a LichroCart 250-4 Lichrospher 100 RP-8 reverse phase column $(250 \times 4 \mathrm{~mm}, 5 \mu \mathrm{m})$; the elution was isocratic, at varying proportions of $\mathrm{CH}_{3} \mathrm{CN}$ in aqueous buffer (sodium hexanesulfonate $10 \mathrm{mM}$, sodium acetate $2.5 \mathrm{mM}$, phosphoric acid $2.5 \mathrm{mM}$; $\mathrm{pH} 6.3$ ) and at a flow rate of $1.0 \mathrm{~mL} / \mathrm{min}$, with detection at $240 \mathrm{~nm}$; paracetamol and the relevant DKPs were used as standards for peak identification; to exemplify, the monitoring of drug release from compound $\mathbf{4 i}$ was carried out using $8 \% \mathrm{CH}_{3} \mathrm{CN}$ in aqueous buffer as HPLC solvent, and retention times for the relevant DKP, paracetamol and $4 \mathbf{i}$ were $9.90,7.70$ and $4.10 \mathrm{~min}$, respectively.

13. Purdie, J. E.; Benoiton, N. L. J. Chem. Soc., Perkin Trans. 2 1973, 13, 1845.

14. Meresaar, U.; Ågren, A. Acta Pharm. Suec. 1968, 5, 85.

15. Jensen, E.; Bundgaard, H. Int. J. Pharm. 1991, 71, 117.

16. Larsen, S. W.; Ankersen, M.; Larsen, C. Eur. J. Pharm. Sci. 2004, 22, 399.

17. Craig, P. N. In Comprehensive Medicinal Chemistry; Hansch, C., Ed.; Pergamon: Oxford, 1990; Vol. 6, p 245.

18. Charton $v$ values taken from Exner, O. In Correlation Analysis in Chemistry; Chapman, N. B., Shorter, J., Eds.; Plenum: New York, 1978; p 439.

19. Lloyd-Williams, P.; Albericio, F.; Giralt, E. Chemical Approaches to the Synthesis of Peptides and Proteins; CRC: Boca Raton, 1997; p 60.

20. The effect of compounds $\mathbf{4 d}, \mathbf{4 h}, \mathbf{4 i}$ and paracetamol on the hepatic levels of glutathione was determined as follows: healthy male BALB/c mice, 17-21 g and 5 weeks old, were allowed free access to water and pelleted food; mice were randomly divided into five groups of four animals each; four groups were treated ip with a single dose of $3.3 \mathrm{mmol} /$ $\mathrm{kg}$ of paracetamol or ester 4 (in $30 \%$ of propyleneglycol); the vehicle was administered ip to a control group; $2 \mathrm{~h}$ post-administration, the animals were sacrificed and the liver removed and kept on ice; glutathione in homogenized liver was immediately determined using 5,5'-dithiobis-(2nitrobenzoic acid) (DTNB) as described in Sedlak, J.; Lindsay, R. H. Anal. Biochem. 1968, 25, 192.

21. Thomsen, K. F.; Bundgaard, H. Int. J. Pharm. 1993, 91, 39. 